\title{
Correction to: Comparison of Uniform and Non-uniform Water Flux Density Approaches Applied on a Mathematical Model of Heat Transfer and Solidification for a Continuous Casting of Round Billets
} CHARLES SOSTENES ASSUNCAO, ROBERTO PARREIRAS TAVARES,
GUILHERME OLIVEIRA, and LUIZ F.P. PEREIRA (D

https://doi.org/10.1007/s11663-019-01661-6

(C) The Minerals, Metals \& Materials Society and ASM International 2019

Correction to: Metallurgical and Materials Transactions B,

Volume 46B, February 2015, p. 366

https://doi.org/10.1007/s11663-014-0200-2

LUIZ F.P. Pereira's name appeared incorrectly on the original publication of this article. It has been corrected here.

CHARLES SOSTENES ASSUNCAO, Graduate Student, ROBERTO PARREIRAS TAVARES, Engineering Professor, and GUILHERME OLIVEIRA and LUIZ F.P. PEREIRA, Undergraduate Students, are with the Department of Metallurgical and Materials Engineering, Universidade Federal de Minas Gerais, Belo Horizonte, Minas Gerais, Brazil. Contact email: Charles.assuncao@vallourec.com

The original article can be found online at https://doi.org/10.1007/ s11663-014-0200-2.

Article published online August 23, 2019. 